Pendayagunaan Lingkungan Sekolah Religius

Untuk Memaksimalkan Pencapaian Kurikulum PAI

\title{
PENDAYAGUNAAN LINGKUNGAN SEKOLAH RELIGIUS UNTUK MEMAKSIMALKAN PENCAPAIAN KURIKULUM PAI
}

\author{
Hilyah Ashoumi, M.Pd.I *
}

\begin{abstract}
Abstrak
Lingkungan sekolah dapat diartikan segala sesuatu yang tampak dan terdapat di sekolah, baik itu alam sekitar maupun setiap individu yang berada di dalamnya. Iklim belajar yang kondusif harus ditunjang oleh berbagai fasilitas belajar yang menyenangkan seperti: sarana, laboratorium, pengaturan lingkungan, penampilan dan sikap guru, hubungan yang hormonis antara peserta didik dengan guru dan antara peserta didik itu sendiri, serta penataan organisasi dan bahan pembelajaran secara tepat, sesuai dengan kemampuan dan perkembangan peserta didik.Pendayagunaan Lingkungan Sekolah yang Religius untuk Memaksimalkan Kurikulum PAI sangat dipengaruhi model penerapan nilai yang mendasarinya, yakni penciptaan budaya religius yang bersifat vertikal dan horizontal. Secara lebih terperinci, pengembangan PAI dalam mewujudkan budaya religius sekolah, menurut Muhaimin dapat dilakukan melalui empat pendekatan: struktural, formal, mekanik dan organik. Sedangkan, Strategi perwujudan budaya religius sebagai perwujudan pengembangan PAI di sekolah, meliputi: Penciptaan suasana religius, Internalisasi Nilai, Keteladanan, Pembiasaan.
\end{abstract}

Kata Kunci: Kurikulum, Pendidikan, Religius.

\section{A. Pendahuluan}

1. Latar Belakang

Sesuai Pasal 12 Bab V UU No. 20 Tahun 2003.“Setiap peserta didik pada setiap satuan pendidikan berhak mendapatkan pendidikan agama sesuai dengan agama yang dianutnya dan diajarkan sesuai oleh pendidik yang beragama." Bila dikaitkan dengan tujuan pendidikan Islam, maka pendidikan agama mestilah mengantarkan seorang peserta didik setidaknya kepada tiga aspek: Pertama, aspek keimanan mencakup seluruh arkanul iman.Kedua, aspek

\footnotetext{
* Dosen PAI Fakultas Agama Islam UNWAHA Tambakberas Jombang
} 


\section{Hilyah Ashoumi}

ibadah mencakup seluruh arkaanul Islam.Ketiga, aspek akhlak mencakup, mencakup seluruh akhlaakulkariimah.

Dalam operasionalnya pendidikan agama Islam di sekolah-sekolah umum diatur oleh Menteri Agama dengan Menteri Pendidikan Nasional.Di sekolahsekolah negeri sejak dari pendidikan dasar sampai pendidikan menengah, pendidikan agama Islam dilaksanakan dua jam pelajaran setiap minggunya.Jika hal ini diterapkan upaya memaksimalkan kompetensi PAI dalam lingkungan sekolah dirasa kurang efektif, karena problem kompetensi tidak hanya berkutat pada pengembangan kognisi tapi juga afeksi dan psikomotor.

Maka perlu adanya kebijakan-kebijakan pihak sekolah untuk mengupayakan terbentuknya lingkungan sekolah yang religius dengan jalan memaksimalkan kompetensi PAI tidak hanya dalam lingkungan kelas saja tapi juga dalam lingkungan sekolah.

2. Rumusan Masalah

a. Apakah Pengertian Lingkungan Sekolah?

b. Bagaimanakah mendayagunakan lingkungan sekolah yang religius untuk Memaksimalkan Kurikulum PAI.?

\section{B. Pembahasan}

1. Lingkungan Sekolah 
Pendayagunaan Lingkungan Sekolah Religius Untuk Memaksimalkan Pencapaian Kurikulum PAI

Dalam arti yang luas lingkungan mencakup iklim dan geografis, tempat tinggal, adat istiadat, pengetahuan, pendidikan dan alam. Dengan kata lain lingkungan ialah segala sesuatu yang tampak dan terdapat dalam alam kehidupan yang senantiasa berkembang, ia adalah seluruh yang ada, baik manusia maupun benda buatan manusia atau alam yang bergerak atau tidak bergerak, kejadian-kejadian atau hal-hal yang mempunyai hubungan dengan seseorang. ${ }^{28}$

Kata sekolah berasal dari Bahasa Latin: skhole, scola, scolae atau skhola yang memiliki arti: waktu luang atau waktu senggang, dimana sekolah adalah kegiatan di waktu luang bagi anak-anak di tengah-tengah kegiatan utama mereka, yaitu bermain dan menghabiskan waktu untuk menikmati masa anakanak dan remaja. Kegiatan dalam waktu luang itu adalah mempelajari cara berhitung, cara membaca huruf dan mengenal tentang moral (budi pekerti) dan estetika (seni). Untuk mendampingi dalam kegiatan scola anak-anak didampingi oleh orang ahli dan mengerti tentang psikologi anak, sehingga memberikan kesempatan yang sebesar-besarnya kepada anak untuk menciptakan sendiri dunianya melalui berbagai pelajaran di atas. ${ }^{29}$ Adapun secara istilah sekolah adalah sebuah lembaga yang dirancang untuk pengajaran siswa (atau "murid") di bawah pengawasan guru.Dengan demikian, lingkungan sekolah dapat diartikan segala sesuatu yang tampak dan terdapat

\footnotetext{
${ }^{28}$ Zakiyah Daradjat, Ilmu Pendidikan Islam (Jakarta : Bumi Aksara, 2008), 63.

${ }^{29}$ Afifah, “Lingkungan Pendidikan Sekolah", http://organisasi.org/kegunaan-manfaat-fungsi-sekolah-dan-kuliahpendidikan-formal-di -indonesia, 07 Mei 2012.
} 


\section{Hilyah Ashoumi}

di sekolah, baik itu alam sekitar maupun setiap individu yang berada di dalamnya. ${ }^{30}$

Lingkungan sekolah yang aman, nyaman dan tertib, optimisme dan harapan yang tinggi dari seluruh warga sekolah, kesehatan sekolah, serta kegiatan yang terpusat pada peserta didik (student-centered activity) merupakan iklim yang dapat membangkitkan nafsu, gairah dan semangat belajar siswa. Iklim belajar yang kondusif merupakan tulang punggung dan faktor pendorong yang dapat memberikan daya tarik sendiri bagi proses belajar, sebaliknya iklim belajar yang kurang menyenangkan akan menimbulkan kejenuhan dan rasa bosan dan pada akhirnya akan menghambat semangat dan motivasi siswa dalam belajar.

Iklim belajar yang kondusif harus ditunjang oleh berbagai fasilitas belajar yang menyenangkan seperti: sarana, laboratorium, pengaturan lingkungan, penampilan dan sikap guru, hubungan yang hormonis antara peserta didik dengan guru dan antara peserta didik itu sendiri, serta penataan organisasi dan bahan pembelajaran secara tepat, sesuai dengan kemampuan dan perkembangan peserta didik. Iklim belajar yang menyenangkan akan membangkitkan semangat dan menumbuhkan aktifitas serta kreatifitas peserta didik. 31

\footnotetext{
${ }^{30}$ Asmaun Sahlan, Mewujudkan Budaya Religius Di Sekolah (Malang: UIN-Maliki Press, 2009), 5.

${ }^{31}$ Asmaun Sahlan, Mewujudkan Budaya Religius Di Sekolah, 50.
} 
Pendayagunaan Lingkungan Sekolah Religius Untuk Memaksimalkan Pencapaian Kurikulum PAI

Berkaitan dengan proses pembelajaran, maka iklim belajar yang kondusif antara lain dapat dikembangkan melalui berbagai layanan dan kegiatan sebagai berikut:

a. Menyediakan pilihan bagi peserta didik yang lambat maupun cepat dalam melakukan tugas pembelajaran. Pilihan dan pelayanan individual bagi peserta didik, terutama bagi mereka yang lambat belajar akan membangkitkan semangat belajar, sehingga membuat mereka betah belajar di sekolah.

b. Memberikan pembelajaran remedial bagi peserta didik yang kurang berprestasi, atau berprestasi rendah. Dalam sistem pembelajaran klasikal sebagian peserta didik akan sulit untuk mengikuti pembelajaran secara optimal dan menuntut peran serta ekstra guru untuk memberikan pembelajaran remedial.

c. Mengembangkan organisasi kelas yang efektif, menarik dan aman bagi perkembangan potensi seluruh peserta didik secara optimal. Termasuk dalam hal ini, adalah menyediakan bahan pembelajaran yang menarik dan menantang bagi peserta didik, serta pengelolaan kelas yang tepat, efektif dan efisien.

d. Menciptakan kerja sama saling menghargai, baik antar peserta didik maupun antara peserta didik dengan guru dan pengelola pembelajaran lain. Hal ini mengandung implikasi bahwa setiap peserta didik memiliki 


\section{Hilyah Ashoumi}

kesempatan yang seluas-luasnya untuk mengemukakan pandangannya tanpa ada rasa takut mendapat sangsi atau dipermalukan.

e. Melibatkan peserta didik dalam proses perencanaan pembelajaran. Dalam hal ini guru harus mampu memposisikan diri menjadi pembimbing dan manusia sumber. Sekali-kali cobalah melibatkan peserta didik dalam proses perencanaan pembelajaran, agar mereka merasa bertanggung jawab terhadap pembelajaran yang dilaksanakan.

f. Mengembangkan proses pembelajaran sebagai tanggung jawab bersama antara peserta didik dan guru, sehingga guru lebih banyak bertindak sebagai fasilitator dan sumber belajar.

g. Mengembangkan sistem evaluasi belajar dan pembelajaran yang menekankan pada evaluasi diri sendiri (self evolution). Dalam hal ini guru sebagai fasilitator harus mampu membantu peserta didik untuk menilai bagaimana mereka dalam memperoleh kemajuan dalam proses belajar yang dilalui. ${ }^{32}$

Ketujuh Layanan dan Kegiatan tersebut diatas termaktub dalam bagan dibawah ini:

\footnotetext{
${ }^{32}$ E. Mulyasa, Kurikulum Tingkatan Satuan Pendidikan, Panduan Praktis (Bandung: Remaja Rosda, 2006),155-
} 157. 
Pendayagunaan Lingkungan Sekolah Religius Untuk Memaksimalkan Pencapaian Kurikulum PAI

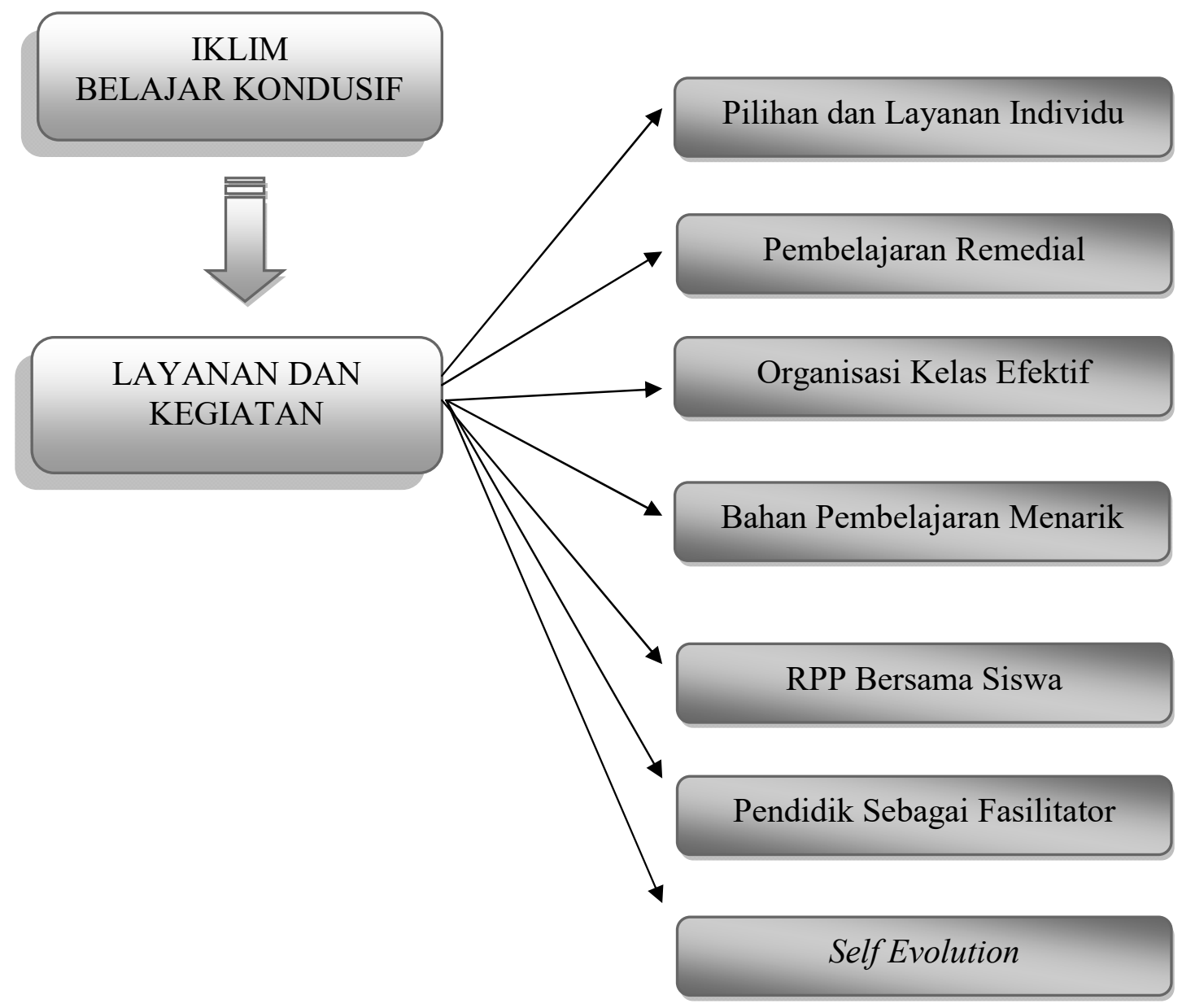

Karena pengembangan KTSP menggunakan pendekatan kompetensi, dan berlandaskan aktivitas serta kemampuan berpikir peserta didik (Student Activity and Thinking Skill), pengembangan KTSP memerlukan ruangan yang fleksibel, serta mudah disesuaikan dengan kebutuhan peserta didik. Luas ruangan dengan jumlah peserta didik juga perlu diperhatikan, bila pemebelajaran dilakukan diruangan tertutup; sedang ditempat terbuka perlu diperhatikan gangguan-gangguan yang datang dari lingkungan sekitar.Sarana dan media pembelajaran juga perlu diatur dan ditata sedemikian rupa, 


\section{Hilyah Ashoumi}

demikian halnya dengan penerangan jangan sampai mengganggu pandangan peserta didik.

Dalam pembelajaran PAI, tersedianya sarana dan prasarana yang memadai mutlak diperlukan mengingat nilai-nilai agama bukanlah rentetan dari bahan ajar yang harus dihafal oleh siswa, tetapi lebih dari itu harus menjadi jiwa, sikap, dan perilaku siswa sehari-hari. Dengan kata lain, nilai-nilai agama yang diajarkan harus dipraktekkan dalam tindakan nyata yang pada akhirnya membentuk satu budaya yaitu budaya religius sekolah.33

2. Pendayagunaan Lingkungan Sekolah Religius untuk Memaksimalkan Kurikulum PAI.

Menurut Muhaimin Penciptaan suasana religius sangat dipengaruhi oleh situasi dan kondisi tempat model itu (suasana religius) akan diterapkan beserta penerapan nilai yang mendasarinya. Pertama, pencipataan budaya religius yang bersifat vertikal dapat diwujudkan dalam bentuk meningkatkan hubungan dengan Allah SWT. Melalui peningkatan secara kuantitas maupun kualitas kegiatan-kegiatan keagamaan di sekolah yang bersifat ubudiyah, seperti : shalat berjamaah, puasa Senin-Kamis, khatm al-Quran, doa bersama dan lainlain. Kedua, penciptaan budaya religius yang bersifat horizontal yaitu lebih

\footnotetext{
${ }^{33}$ Asmaun Sahlan, Mewujudkan Budaya Religius Di Sekolah, 50.
} 
Pendayagunaan Lingkungan Sekolah Religius Untuk Memaksimalkan Pencapaian Kurikulum PAI

mendudukkan sekolah sebagai institusi sosial religius, seperti : persaudaraan, kedermawanan, kejujuran, saling menghormati dan sebagainya. ${ }^{34}$

\begin{tabular}{|c|c|}
\hline \multicolumn{2}{|c|}{ Penciptaan Suasana Religius di Sekolah } \\
\hline Bersifat Vertikal & Bersifat Horisontal \\
\hline Shalat Jama'ah, Puasa Senin- & $\begin{array}{c}\text { Persaudaraan, Kedermawanan, } \\
\text { Kejujuran, dan Saling } \\
\text { Kamis, Khatm al-Qur'an, Do'a } \\
\text { Bersama. }\end{array}$ \\
\hline
\end{tabular}

Secara lebih terperinci, pengembangan PAI dalam mewujudkan budaya religius sekolah, menurut Muhaimin dapat dilakukan melalui empat pendekatan:

a. Pendekatan struktural, yaitu strategi pengembangan PAI dalam mewujudkan budaya religius di sekolah sudah menjadi komitmen dan kebijakan pimpinan sekolah, sehingga lahirnya berbagai yang mendukung terhadap lahirnya berbagai kegiatan keagamaan di sekolah beserta berbagai sarana dan prasarana pendukungnya termasuk dari sisi pembiayaan. Dengan demikian pendekatan ini lebih bersifat "topdown" yakni kegiatan keagamaan yang dibuat atas prakarsa atau instruksi dari pejabat atau pimpinan sekolah.

b. Pendekatan formal, yaitu strategi pengembangan PAI dalam mewujudkan budaya religus sekolah dilakukan melalui peng-optimal-an kegiatan belajar mengajar (KBM) mata pelajaran PAI di sekolah. Dengan demikian, dalam

\footnotetext{
${ }^{34}$ Muhaimin, Strategi Belajar Mengajar : Penerapannya dalam Pembelajaran Pendidikan Agama (Surabaya : Citra Media, 1996), 61-62.
} 


\section{Hilyah Ashoumi}

pendekatan formal ini, guru PAI mempunyai peran yang lebih banyak dibanding guru-guru mata pelajaran lainkarena bagaimana meningkatkan kualitas mutu pembelajaran PAI di kelas sepenuhnya merupakan tanggung jawab guru PAI.

c. Pendekatan mekanik, yaitu strategi pengembangan PAI dalam mewujudkan budaya religius sekolah didasari oleh pemahaman bahwa kehidupan terdiri atas berbagai aspek, dan pendidikan dipandang sebagai penanaman dan pengembangan seperangkat nilai kehidupan, yang masing-masing bergerak dan berjalan menurut fungsinya. Pendekatan mekanik ini di sekolah dapat diwujudkan dengan meningkatkan kuantitas dan kualitas kegiatan ekstrakurikuler bidang agama. Artinya dengan semakin menyemarakkan berbagai kegiatan ekstrakurikuler bidang agama di sekolah, warga sekolah terutama siswa tidak hanya memahami PAI secara kurikuler di kelas saja, namun juga diwujudkan dalam berbagai kegiatan ekstrakurikuler yang terintegrasi denga kegiatan sekolah lainnya. Dalam pendekatan ini, pengurus OSIS khususnya bidang keagamaan memiliki peran penting dalam pengembangan PAI dalam mewujudkan budaya religius sekolah.

d. Pendekatan organik,yaitu pencipataan suasana religius yang disemangati oleh pandangan bahwa pendidikan agama adalah kesatuan atau sebagai sistem sekolah yang berusaha mengembangkan pandangan atau semangat hidup agamis, yang dimanifestasikan dalam sikap hidup, perilaku dan 
Pendayagunaan Lingkungan Sekolah Religius Untuk Memaksimalkan Pencapaian Kurikulum PAI

keterampilan hidup yang religius dari seluruh warga sekolah. Artinya strategi pengembangan PAI dalam mewujudkan budaya religius sekolah sudah menjadi komitmen dan mendapat dukungan dari seluruh warga sekolah. ${ }^{35}$ Secara global pembagian pendekatan budaya religius di Sekolah adalah sebagaimana tergambarkan dalam bagan di bawah ini:

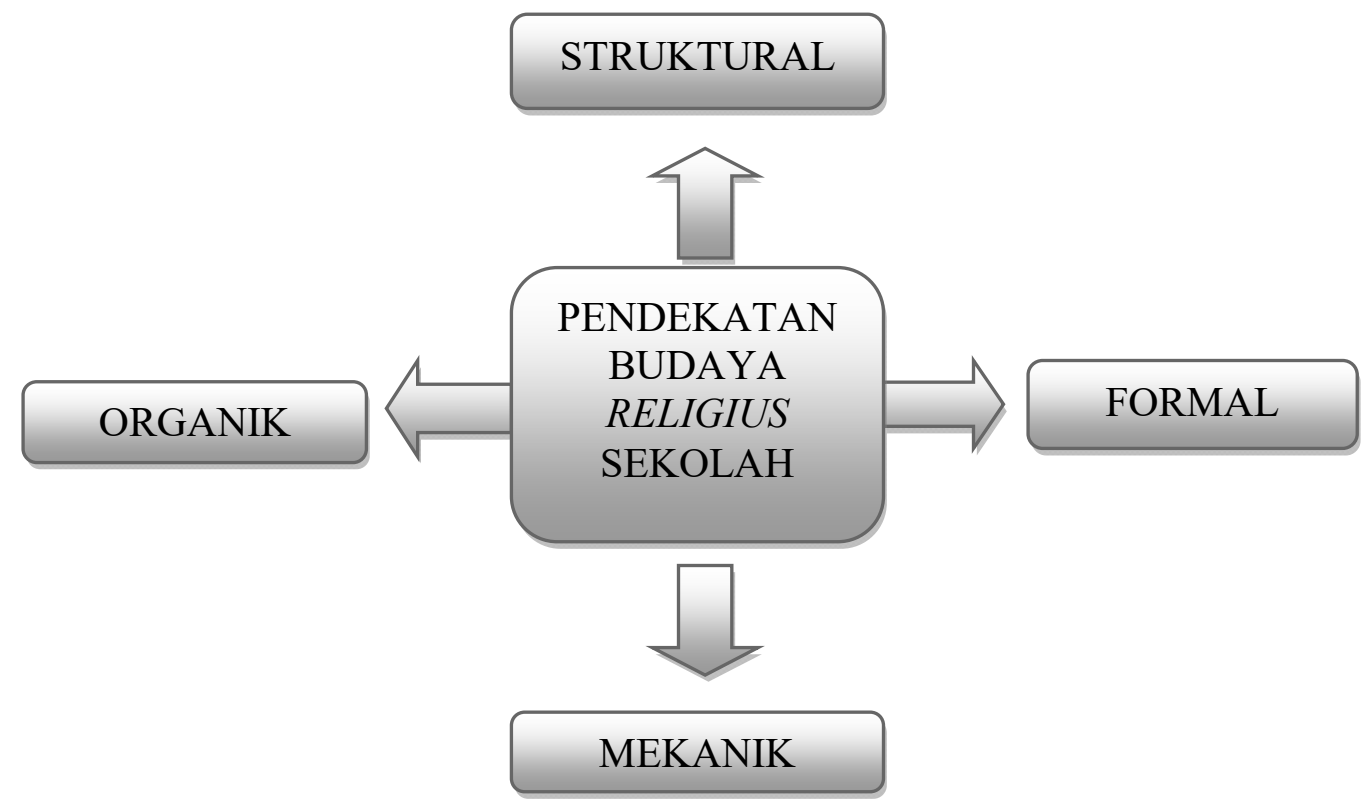

Strategi perwujudan budaya religius sebagai perwujudan pengembangan PAI di sekolah, meliputi:36Pertama, Penciptaan suasana religius,penciptaan suasana religius merupakan upaya untuk mengkondisikan suasana dengan nilai-nilai dan perilaku religius (keagamaan). Penciptaan suasana religius seperti: a) berdoa bersama sebelum pembelajaran, kegiataan ini bisa dilakukan setiap awal dan akhir pelajaran. b) khatm al-Quran, kegiatan ini bisa diadakan

\footnotetext{
${ }^{35}$ Ibid, 305-307.

${ }^{36}$ Asmaun Sahlan, Mewujudkan Budaya Religius Di Sekolah, 48-49.
} 


\section{Hilyah Ashoumi}

setiap bulan sekali. c) shalat jum'at. d) istighasah (doa bersama).e) Peringatan Hari Besar Islam (PHBI). f) Kegiatan pondok ramadlan. Hal ini menunjukkan, pemimpin sekolah memiliki pemahaman bahwa untuk menjadi orang yang pandai, pintar, berguna bagi agama, nusa dan bangsa tidak hanya semata-mata dikarenakan ketajaman akal, ketepatan metodologi pembelajaran dan kesungguhan hati, tetapi juga tergantung pada kesucian hati, doa restu orang tua, dan upaya ritual lainnya.

Kedua, Internalisasi Nilai, Talidzuhu Ndara menyatakan agar budaya tersebut menjadi nilai-nilai yang tahan lama, maka harus ada proses internalisasi nilai. Dalam bahasa inggris, internalized berarti to incorporate in oneself. Jadi, internalisasi berarti proses menanamkan dan menumbuh kembangkan suatu niali atau budaya menjadi bagian diri (self) orang yang bersangkutan. Penanaman dan penumbuhkembangan nilai tersebut dilakukan melalui berbagai didaktik metodik pendidikan dan pengajaran. ${ }^{37}$ Proses internalisasi nilai ini tidak hanya dilakukan oleh guru agama saja, melainkan juga semua guru, dimana mereka menginternalisasikan ajaran agama dengan keilmuan yang mereka miliki seperti guru biologi, matematika, fisika, kimia yang mengaitkan materi ajardengan al-Qur'an dan nilai-nilai agama Islam. Pesan-pesan moral yang disampaikan oleh guru umum kadangkala lebih mengena kepada hati siswa, sehingga proses internalisasi akan dapat masuk ke

\footnotetext{
${ }^{37}$ Talidzuhu Dhara, Budaya Organisasi (Jakarta: Rineka Cipta, 1997), 82.
} 


\section{Pendayagunaan Lingkungan Sekolah Religius Untuk Memaksimalkan Pencapaian Kurikulum PAI}

dalam fikiran dan tindakan para siswa, karena mereka senantiasa diingatkan dengan nilai-nilai agama.

Ketiga, Keteladanan, merupakan perilaku yang memberikan contoh kepada orang lain dalam hal kebaikan. Rasulullah SAW. sendiri diutus kedunia tidak lain adalah untuk memyempurnakan akhlak, dengan memberikan contoh pribadi beliau sendiri. Sebagaimana sabda Rasulullah SAW:

$$
\text { انما بعثت لأتمم مكارم الأخلاق (رواه احمد) }
$$

"sesungguhnyaaku (Muhammad) diutus, untuk menyempurnakan akhlak". 38 Aspek keteladanan ini bisa diterapkan di sekolah melalui: a) berakhlak yang baik, para guru dan karyawan memberikan akhlak yang baik, dengan cara dan sikap mereka yang menjunjung tinggi toleransi sesama. b) menghormati yang lebih tua, walaupun posisi mereka tukang kebun atau karyawan. c) memakai busana muslimah. d) menyapa dan menguapkan salam.

Keempat, Pembiasaan, hal baik yang dilakukan secara contineu yang dilakukan seluruh warga sekolah, menurut muhaimin pembiasaan adalah memberikan kesempatan kepada peserta didik untuk senantiasa mengamalkan ajaran agamanya dan atau akhlak mulia. ${ }^{39}$ Pembiasaan dalam beragama dapat menciptakan kesadaran dalam beragama. Zakiah Daradjat melukiskan tentang pembiasaan yang pernah dilakukan oleh para sufi. Mereka merasa bahwa Allah selalu hadir dalam hati, kejadian ini tercipta melalui proses sebagai berikut: awal lisan dibiasakan untuk berdzikir kepada Allah, maka lisan

\footnotetext{
${ }^{38}$ HR. Ahmad, 8938. CD Hadith Kutub al Tis'ah.

${ }^{39}$ Muhaimin, Paradigma Pembiasaan Islam (Bandung: Rosda Karya, 2006), 301.
} 


\section{Hilyah Ashoumi}

senantiasa mengucap kata Allah. ${ }^{40}$ seperti: a)menyapa,b) mengucap salam dan senyum,c) shalat berjama'ah, d) istighasah, e) khatm al-Qur'an, f) puasa seninkamis, g) shalat dhuha.

\begin{tabular}{|c|l|l|}
\hline No & \multicolumn{1}{|c|}{$\begin{array}{c}\text { Strategi Perwujudan Budaya } \\
\text { Religius di Sekolah }\end{array}$} & \multicolumn{1}{c|}{ Aplikasi } \\
\hline 1. & $\begin{array}{l}\text { Pengkondisisan Suasana } \\
\text { Sekolah dengan Nilai-Nilai dan } \\
\text { Perilaku Religius. }\end{array}$ & $\begin{array}{l}\text { a) Berdoa bersama sebelum } \\
\text { pembelajaran, dilakukan setiap awal dan } \\
\text { akhir pelajaran. b) Khatm al-Quran, } \\
\text { diadakan setiap bulan sekali. c) Shalat } \\
\text { jum'at. d) Istighasah (Doa Bersama). e) } \\
\text { Peringatan Hari Besar Islam (PHBI). f) } \\
\text { Kegiatan pondok ramadlan. }\end{array}$ \\
\hline 2. & $\begin{array}{l}\text { Peng-internalisasi-an Ajaran } \\
\text { Agama pada Mata Pelajaran } \\
\text { lainnya. }\end{array}$ & $\begin{array}{l}\text { Guru biologi, matematika, fisika, kimia } \\
\text { dan seluruh Mata Pelajaran yanga ada di } \\
\text { Sekolah mengaitkan materi ajar dengan } \\
\text { al-Qur'an dan nilai-nilai agama Islam. }\end{array}$ \\
\hline 3. & Penerapan Aspek Keteladanan & $\begin{array}{l}\text { a) Berakhlak yang baik, para guru dan } \\
\text { karyawan memberikan akhlak yang baik, } \\
\text { dengan cara dan sikap mereka yang } \\
\text { menjunjung tinggi toleransi sesama. b) } \\
\text { Menghormati yang lebih tua, walaupun } \\
\text { posisi mereka tukang kebun atau } \\
\text { karyawan. c) Memakai busana muslimah. } \\
\text { d) Menyapa dan Menguapkan salam. }\end{array}$ \\
\hline 4. & Pembiasaan Beragama & $\begin{array}{l}\text { a) Menyapa, b) Mengucap salam dan } \\
\text { senyum, c) Shalat berjama'ah, d) } \\
\text { Istighasah, e) Khatm al-Qur'an, f) Puasa } \\
\text { Senin-Kamis, g) Shalat Dhuha. }\end{array}$ \\
\hline
\end{tabular}

\section{Penutup}

Lingkungan sekolah dapat diartikan segala sesuatu yang tampak dan terdapat di sekolah, baik itu alam sekitar maupun setiap individu yang berada di

${ }^{40}$ Zakiah Daradjat, Ilmu Jiwa Agama (Jakarta: Bulan Bintang, 1976). 4. 
Pendayagunaan Lingkungan Sekolah Religius Untuk Memaksimalkan Pencapaian Kurikulum PAI

dalamnya. Iklim belajar yang kondusif harus ditunjang oleh berbagai fasilitas belajar yang menyenangkan seperti: sarana, laboratorium, pengaturan lingkungan, penampilan dan sikap guru, hubungan yang hormonis antara peserta didik dengan guru dan antara peserta didik itu sendiri, serta penataan organisasi dan bahan pembelajaran secara tepat, sesuai dengan kemampuan dan perkembangan peserta didik.

Pendayagunaan Lingkungan Sekolah yang Religius untuk Memaksimalkan Kurikulum PAI sangat dipengaruhi model penerapan nilai yang mendasarinya, yakni penciptaan budaya religius yang bersifat vertikal dan horizontal. Secara lebih terperinci, pengembangan PAI dalam mewujudkan budaya religius sekolah, menurut Muhaimin dapat dilakukan melalui empat pendekatan: struktural, formal, mekanik dan organik. Sedangkan, Strategi perwujudan budaya religius sebagai perwujudan pengembangan PAI di sekolah, meliputi: Penciptaan suasana religius, Internalisasi Nilai, Keteladanan, Pembiasaan. 


\section{Hilyah Ashoumi}

\section{Daftar Pustaka}

Daradjat, Zakiyah, 2008. Ilmu Pendidikan Islam.Jakarta : Bumi Aksara.

1976.Ilmu Jiwa Agama. Jakarta: Bulan Bintang.

Dhara, Talidzuhu, 1997. Budaya Organisasi. Jakarta: Rineka Cipta.

HR. Ahmad, 8938. CD Hadith Kutub al Tis'ah.

Muhaimin, 1996.Strategi Belajar Mengajar : Penerapannya dalam Pembelajaran Pendidikan Agama. Surabaya : Citra Media.

-----------, 2006.Paradigma Pembiasaan Islam.Bandung: Rosda Karya.

Mulyasa,E, 2006.Kurikulum Tingkatan Satuan Pendidikan, Panduan Praktis (Bandung: Remaja Rosda.

Sahlan, Asmaun, 2009.Mewujudkan Budaya Religius Di Sekolah.Malang: UIN-Maliki Press. 